\title{
Dakwah di Kalangan Prajurit
}

\author{
Deni Rachyudi ${ }^{1}$, Zaenal Abidin ${ }^{2}$, Yusuf Zaenal Abidin ${ }^{3}$ \\ ${ }^{1}$ Pusat Kesenjataan Artileri Pertahanan Udara, Bandung \\ 2Jurusan Komunikasi dan Penyiaran Islam, Fakultas Dakwah dan Komunikasi, \\ UIN Sunan Gunung Djati, Bandung \\ 3 Jurusan Komunikasi dan Penyiaran Islam, Program Pascasarjana, \\ UIN Sunan Gunung Djati, Bandung \\ *Email :danramil1313@gmail.com
}

\begin{abstract}
The purpose of this research is to study the attention of soldiers on da'wah activities, applying good after listening Da'wah among soldiers, and invite and do good deeds I good deeds and abstain from the actions of the ungodly and dolly. The results of this study, found that: First, the tasks and challenges facing soldiers are heavier and complex both internal and external, while some of the soldiers have not had a strong mental resilience, as a consequence the soldiers are easily affected by the less conducive environments. For that it required a strong mental readiness for soldiers.Second, mental condition of tough soldiers obtained through the intensification of bintal activities, optimization of the function of command functions in unity and empowerment of nodal institutions in the unity and the excitement of religious life, mental guidance material to the soldiers must be given intactly including spiritual mental guidance, mental nationalism and militant and dignified. Third, With the mental condition of a healthy and tough warrior then the violations can be minimized so that it can affect the successful implementation of duties and family soldiers get happiness and prosperity. coaching ideology and mental coaching kejuangan so it can be realized soldiers sarnta marga cautious.
\end{abstract}

Keywords: soldier; violations; mental guidance.

\begin{abstract}
ABSTRAK
Tujuan dari penelitian ini untuk mengetahui perhatian prajurit terhadap dakwah di kalangan prajurit, pemahaman prajurit setelah menyimak dakwah dan peran bintaldam III/Slw. dalam memberikan perhatian dakwah di kalangan prajurit. Penelitian ini menggunakan metode kualitatif. Hasil penelitian menemukan bahwa: pertama, tugas dan tantangan yang dihadapi prajurit semakin berat dan kompleks baik yang bersifat internal maupun eksternal, sedangkan sebagian dari para prajurit belum memiliki ketahanan mental yang tangguh, akibatnya prajurit mudah terpengaruh lingkungan yang kurang kondusif. Untuk itu diperlukan kesiapan mental yang tangguh bagi prajurit. Kedua, kondisi mental prajurit yang tangguh diperoleh melalui intensifikasi kegiatan bintal, optimalisasi Bintal Fungsi Komando di kesatuan dan pemberdayaan lembaga bintal di kesatuan serta
\end{abstract}


D. Rachyudi, Z. Abidin, Y. Z. Abidin

penggairahan kehidupan beragama, materi pembinaan mental kepada prajurit harus diberikan secara utuh yang meliputi pembinaan mental rohani, pembinaan mental ideologi dan pembinaan mental kejuangan sehingga dapat terwujud prajurit sapta marga yang bertakwa, nasionalisme dan militan serta bermartabat. Ketiga, dengan kondisi mental pajurit yang sehat dan tangguh maka pelanggaran dapat diminimalisir sehingga dapat berpengaruh pada keberhasilan pelaksanaan tugas serta keluarga prajuritpun mendapatkan kebahagiaan dan sejahtera.

Kata Kunci : prajurit, dakwah, pembinaan mental

\section{PENDAHULUAN}

Kondisi mental seseorang dapat dilihat atau diamati dari dua aspek yaitu dari tingkat penghayatan dan pengamalan nilai-nilai mental serta dari tingkat pelanggaran yang dilakukan. Ketahanan pribadi yang perlu dikembangkan pada dasarnya berkaitan erat dengan lingkungan dimana setiap individu berada. Seperti diketahui lingkungan terdekat individu adalah keluarga.

Oleh karena itu ketahanan pribadi juga berkaitan erat dengan ketahanan keluarga, begitu juga sebaliknya. Dari pemahaman, penghayatan dan pengamalan nilai-nilai mental berdasarkan hasil litbang Bintal maupun data Spamad serta lembaga yang kompeten diperoleh data antara lain, Dari aspek rohani masih banyak ditemukan prajurit yang belum memahami agamanya sehingga tidak mampu mengamalkannya dengan baik dan benar (hasil litbang Bintal TA. 2017 terdapat $10 \%$ prajurit Satpur yang bertugas di Provinsi NAD belum memahami agamanya).Dari aspek Ideologi terdapat temuan baru anggota Angkatan Darat yang terindikasi tidak bersih lingkungan (Data Spamad menunjukan pada akhir TA. 2017 terdapat sebanyak 119 orang) dan beberapa oknum anggota disinyalir terlibat dalam konflik komunal di beberapa daerah konflik. Dari aspek kejuangan dapat kita lihat menurunnya militansi sebagian prajurit yang bertugas di daerah rawan sehingga mereka cenderung sekedar mencari selamat akibatnya tugas pokok tidak dapat tercapai. Disamping itu tingkat keteladanan unsur pimpinan cenderung menurut (data Litbang Bintal terhadap tingkat keteladanan unsur pimpinan di Satpur/Banpur pada tahun 2016 sebesar 48,31 \% dan pada tahun 2016 menurun menjadi $37 \%$ ).

Kondisi mental prajurit saat ini cukup memprihatinkan karena demikian mudahnya mereka terpengaruh lingkungan masyarakat.Sedangkan generasi muda Indonesia saat ini terindikasi $34 \%$ terpengaruh narkoba dan 150.000 orang tiap tahun mati karena narkoba (sumber data: BNN Thn. 2016), angka perzinahan remaja berusia 15 tahun mencapai 85 \% (data Kantor Berita Antara Thn. 2017). Sedangkan kasus perceraian suami istri anggota cenderung meningkat dari tahun ke tahun.Dari tingkat pelanggaran, hasil evaluasi yang dilakukan oleh Spamad untuk tahun 2017 telah terjadi peningkatan pelanggaran yang dilakukan oleh prajurit Angkatan Darat dan keluarganya antara lain THTI, Desersi, pelanggaran lalin, perkelahian, pencurian dengan kekerasan, narkoba, insubordinasi dan lain 
sebagainya. Pelanggaran yang terjadi dikalangan prajurit antara tahun 2016 dengan tahun 2017 terjadi peningkatan yang signifikan. Pada tahun 2016 terjadi 1801 kasus pelanggaran yang terdiri dari 23 jenis kasus dan melibatkan 2202 orang personel, sedangkan pada tahun 2017 meningkat dengan melibatkan sebanyak 3117 orang personel.

Adapun beberapa teori yang digunakan pada pennelitian ini sebagai berikut: Seleksi Mental dan Bintal di Lemdik/Satuan, Seleksi Mental. Dalam Psikologi pendidikan agama menyatakan bahwa faktor dasar (sifat bawaan) dan ajar (milliau) sangat berpengaruh terhadap tingkah laku seseorang, namun faktor dasar ternyata berpengaruh lebih kuat dibanding faktor ajar.(Pembinaan Mental ABRI, 1990: 7) Karena itu seleksi mental bagi calon prajurit menjadi demikian penting. Namun pelaksanaan seleksi mental dalam rekrutmen calon prajurit difokuskan pada mental ideologi (MI), sehingga tingkat keimanan dan ketakwaan atau kesadaran beragama dan mental kejuangan calon prajurit yang lulus belum memahami ajaran agamanya dan belum mampu mengamalkan dengan baik.

Pelaksanaan Bintal di satuan dirasakan kurang maksimal dan belum utuh. Sebagian satuan melaksanakan Bintal masih terfokus kepada ceramah agama yang bersifat monoton dan pelaksanaannya pun hanya bersifat insidentil, belum terjadual dengan baik. Demikian pula di Lemdik masih sebatas dalam jam pelajaran dengan alokasi materi Bintal terbatas dan kurang diimbangi dengan kegiatan pengasuhan khususnya pengalaman agama. Namun demikian ada upaya-upaya Dansat di beberapa Satuan yang cukup baik, tetapi jumlahnya sedikit sehingga gaungnya kurang luas dirasakan oleh Satuan lain.

Faktor-faktor yang mempengaruhi Pembinaan Mental.Terjadinya pelanggaran dalam kehidupan prajurit dan keluarganya sebagian besar bukanlah hal yang spontan terjadi begitu saja tanpa ada penyebabnya. Ada beberapa faktor yang mempengaruhi terjadinya peningkatan pelanggaran di kalangan prajurit dan keluarganya, (Operasi Yustisi 2017) yaitu Faktor Eksternal, antara lain:satu Kepemimpinan yang tidak tegas, dua Kurang optimalnya pelakasanaan Binsat, tiga Kurang kepedulian Dansat terhadap kesejahteraan anggota, empat Lingkungan pergaulan yang tidak sehat, lima Pemberian penghargaan dan sanksi yang tidak proporsional.Faktor Internal, antara lain: satu Kondisi mental yang lemah, duaKehidupan rumah tangga yang kurang harmonis, tigaKeadaan ekonomi yang kurang memadai, empatRendahnya kesadaran hukum dan agama, lima Latar belakang kehidupan sebelum menjadi prajurit

Konsep Pembinaan Mental.Arti dan Hakikat Mental, Mental adalah kondisi jiwa yang terpantul dalam sikap dan perilaku seseorang terhadap berbagai situasi yang dihadapi.Pembinaan Mental adalah segala UPK untuk membina, memelihara dan meningkatkan serta memantapkan mental prajurit TNI berdasarkan Agama, Pancasila, Sapta Marga, Sumpah Prajurit dan doktrin KEP melalui Pembinaan Rohani, Mental Ideologi dan Mental Kejuangan sehingga mampu melaksanakan tugas dengan baik dan berhasil. Hakikat Mental, Hakikat mental prajurit TNI adalah sikap dan perilaku prajurit, cerminan dari pemahaman dan penghayatannya terhadap nilai-nilai Sapta Marga sebagai pedoman hidupnya. Dalam Sapta Marga 
D. Rachyudi, Z. Abidin, Y. Z. Abidin

terdapat nilai-nilai ketakwaan (marga ke tiga), nasionalisme (marga kesatu dan kedua), dan militansi sebagai bayangkari negara (marga keempat hingga ke tujuh). Karena itu hakikat mental prajurit Angkatan Darat adalah sikap dan perilaku prajurit Sapta Marga yang bertakwa, nasionalis dan militan.

Masalah yang akan dikaji pada proses penelitian kegiatan Dakwah dikalangan prajurit Rumusan masalahnya adalah sebagai berikut: Bagaimana perhatian para prajurit terhadap Dakwah dikalangan prajurit ?, Bagaimana pemahaman para prajurit setelah menyimak Dakwah dikalangan prajurit ? dan Bagaimana peran Pembinaan mental Kodam III/SLW dalam memberikan pengertian Dakwah dikalangan prajurit ? Untuk menganalisis pertanyaan tersebut digunakan metode penelitian kualitatif dengan pengumpulan data menggunakan observasi, wawancara dan dokumentasi.

\section{HASIL DAN PEMBAHASAN}

Penelitian ini dilakukan di Kantor Balak Bintaldam III/Slw Jalan Lembong Bandung, Berdasarkan hasil kajian secara teoritis dan empiris serta berdasarkan analisis temuan di lapangan, data yang dikemukakan pada bab-bab terdahulu maka, di peroleh hasil pembahasan Dakwah di Kalangan Prajurit Sbb :

\section{Perhatian Prajurit terhadap Dakwah di Kalangan prajurit}

Prajurit diharapkan untuk mempedomani aspek Disiplin prajurit yaitu dengan ketaatan karena dari ketaatanlah kinerja institusi akan terwujud secara memadai dan Seorang Komandan mempunyai peranan yang paling menonjol dalam pembinaan dan penegakan disiplin mental karena dia yang langsung berhubungan dengan anak buahnya serta mempunyai wewenang penuh. Oleh karena itu kualitas kepemimpinan para Komandan satuan menjadi barometer disiplin di lingkungan Satuan, apalagi dihadapkan pada filosofi dalam kehidupan tentara bahwa tidak ada bawahan yang salah, yang salah itu adalah Komandan dan tidak ada bawahan yang jelek karena yang jelek itu adalah Komandan.

Dari filosofi ini betapa besar peranan kepemimpinan Komandan dalam hal pembinaan dan penegakan hukum. Aspek tinjauan agama islam terhadap pelanggaran prajurit Untuk mencegah pelanggaran yang terjadi diperlukan langkah-langkah yang tepat sesuai dengan norma dan ketentuan agama islam yang berlaku maka disampaikan tinjauan agama Islam terhadap pelanggaran prajurit berupa ayat-ayat Al-quran dan hadis sebagai pedoman agar mereka selamat dari hal-hal yang dilarang oleh Allah SW'T.

\section{Pemahaman Prajurit setelah Menyimak Dakwah}

Pemahaman prajurit dalam hal ini adalah: Pertama Prajurit Memahami Perangkat Penegakan Hukum di Satuan yang terdiri dari Komandan, staf, piranti lunak dan perwira hukum. Kedua Prajurit Memahami Peran Komandan Dalam Penegakkan Hukum yang terdiri dari Hukum dalam fungsi Komando, ketiga Kewenangan Komandan dalam Hukum Administrasi, keempat Kewenangan Komandan dalam Hukum Disiplin, kelima Kewenangan Komandan dalam Hukum Pidana, keenam 
Prajurit Memahami Landasan Yuridis Tanggungjawab Komandan, ketujuh Hambatan Dalam Penegakan Hukum Prajurit yaitu Respons Komandan, Para Komandan kurang memahami tugas dan Kewenangannya, Sikap Diskriminatif dalam Penyelesaian Masalah.

\section{Peran Pembinaan Mental Kodam III/Siliwangi DALAM Memberikan Pengertian terhadap Dakwah}

Konsep yang diberikan kepada para prajurit adalah sbb : Pertama, Komponen Bintal Angkatan Darat.Pembinaan Mental kepada prajurit merupakan suatu sistem yang terdiri dari tiga komponen pembinaan, meliputi: satu Pembinaan Mental RohaniPembinaan Mental Rohani adalah pembinaan mental/kejiwaan berdasarkan nilai-nilai yang terdapat dalam ajaran agama untuk meningkatkan keimanan dan ketaqwaan terhadap Tuhan Yang Maha Esa, mempertinggi moral/akhlak yang luhur baik dalam hubungan manusia dengan Tuhannya, manusia dengan sesamanya maupun dengan dirinya sendiri. Agama yang dianut para prajurit beserta keluarganya adalah agama Islam, Protestan, Katolik, Hindu dan Budda. Apabila nilai-nilai rohani telah tertanam pada prajurit akan dapat meningkatkan motivasi (karena iman adalah sumber motivasi) dan mengendalikan perilaku sehingga menjadi manusiabermoral/bermartabat.

Dua, Pembinaan Mental Ideologi, Pembinaan Mental Ideologi adalah pembinaan mental/kejiwaan berdasarkan nilai-nilai yang terkandung dalam ideologi Pancasila untuk membina dan meningkatkan kesadaran berbangsa dan bernegara (nasionalisme) baik dalam kehidupan sebagai warga negara Indonesia maupun sebagai insan Prajurit yang berjiwa Sapta Marga serta memegang teguh Sumpah Prajurit. Dengan mental ideologi yang mantap akan melahirkan kesetiaan dan kecintaan terhadap NKRI dan Kesatuannya serta kedisiplinan dan jiwa korsa yang positif/konstruktif. Nilai-nilai mental ideologi juga menjadi motivasi utama dalam kehidupan berbangsa dan bernegara.

Tiga Pembinaan Mental Kejuangan, Pembinaan Mental Kejuangan adalah Pembinaan Mental/kejiwaan berdasarkan tradisi kepahlawanan bangsa dan TNI yang bersumber dari nilai-nilai Agama, Pancasila, Sapta Marga dan Sumpah Prajurit serta budayakan bangsa yang mengandung jiwa atau semangat pengabdian, ikhlas berkorban, tahan menderita, tidak cepat putus asa. Mental kejuangan dalam aplikasinya mencakup kejuangan dalam tugas individu, keprajuritan dan kepemimpinan.Semangat juang dan nasionalisme dari suatu bangsa akan terpancar dari kualitas dan ketangguhan bangsa dalam menghadapi berbagai ancaman, sebagaimana dibuktikan dalam peristiwa heroik 10 Nopember 1945 di Surabaya dan Peristiwa Palagan Ambarawa. Semangat juang dengan semboyan "Merdeka atau Mati" menjadi motivasi yang kuat untuk mempertahankan NKRI. Motivasi tersebut bagi segenap prajurit TNI harus dibina agar tumbuh subur. Semangat juang akan melahirkan semangat pantang menyerah, mendahulukan kepentingan bangsa dan negara di atas kepentingan pribadi dan golongan.

Kedua, Esensi Bintal Angkatan Darat.Esensi Pembinaan Mental prajurit 
D. Rachyudi, Z. Abidin, Y. Z. Abidin

merupakan nilai-nilai dasar yang terkandung dalam komponen Bintal, yaitu pembinaan mental rohani untuk mewujudkan prajurit yang beriman dan bertakwa, pembinaan mental ideologi untuk mewujudkan prajurit yang berjiwa nasionalis dan pembinaan mental kejuangan untuk mewujudkan militansi.

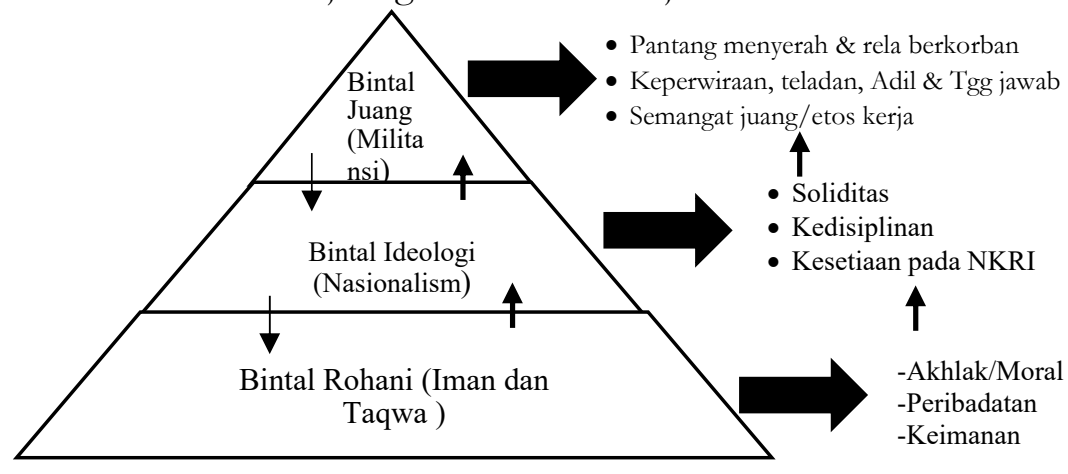

Gambar 1. Esensi bintal prajurit

Sumber : Dinas Pembinaan Mental Angkatan Darat

Bintal Rohani, Pembinaan Mental Rohani mengandung tiga nilai dasar dalam membangunmanusia yang bertakwa, yaitu manusia yang memiliki kesalehan spiritual dan kesalehan sosial. Ketiga nilai dasar itulah:satuKeimanan kepada Tuhan Yang Maha Esa sebagai dasar dari segala nilai dan sumber motivasi. Dua, Peribadatan atau pengabdian kepada Tuhan, baik yang bersifat vertikal maupun horizontal, sebagai pengamalan nyata dari keimanan.Tiga,Akhlak / moralitas, baik dalam hubungan dengan Tuhan dan sesama maupun dengan dirinya sendiri serta lingkungan alam sekitarnya.

Bintal Ideologi, Bintal Ideologi mengandung tiga nilai dasar utama dalam membangun warga negara Indonesia yang nasionalis, meliputi: Satu,Kesetiaan dan kecintaan kepada NKRI. Kesetiaan dan Cinta Tanah Airmerupakan suatu kewajiban bagi seluruh warga negara secara utuh dan bulat.Dua, Kedisiplinan pribadi maupun nasional yang berarti sadar posisi dan rela serta taat terhadap semua aturan yang berlaku, Tiga,Soliditas. Persatuan dan kesatuan sebagai bangsa Indonesia yang memiliki kebhinekaan.

Bintal Kejuangan, Bintal Kejuangan dilaksanakan untuk menghasilkan semangat militansi bagi prajurit. Kata "Militansi" menurut Kamus Besar Bahasa Indonesia berarti bersemangat atau bergairah. Nilai-nilai yang akan terwujud dari Bintal Kejuangan yang menghasilkan militansi bagi prajurit adalah, satu,Semangat juang dan etos kerja yang tinggi dalam setiap pelaksanaan tugas sesuai bidang, fungsi dan peran masing-masing.DuaKeperwiraan (keteladanan, keadilan dan tanggung jawab) dalam mengemban suatu amanat atau kepemimpinan (kepercayaan bangsa dan negara).Tiga, Pantang menyerah dan rela berkorban dalam mengemban tugas negara demi tegak dan utuhnya NKRI.

Ketiga, Sinergisme Nilai-Nilai Komponen Bintal.Pembinaan Mental Prajurit yang terdiri dari tiga komponen pembinaantidaklah berdiri sendiri-sendiri, 
melainkan saling terkait satu dengan yang lainnya.

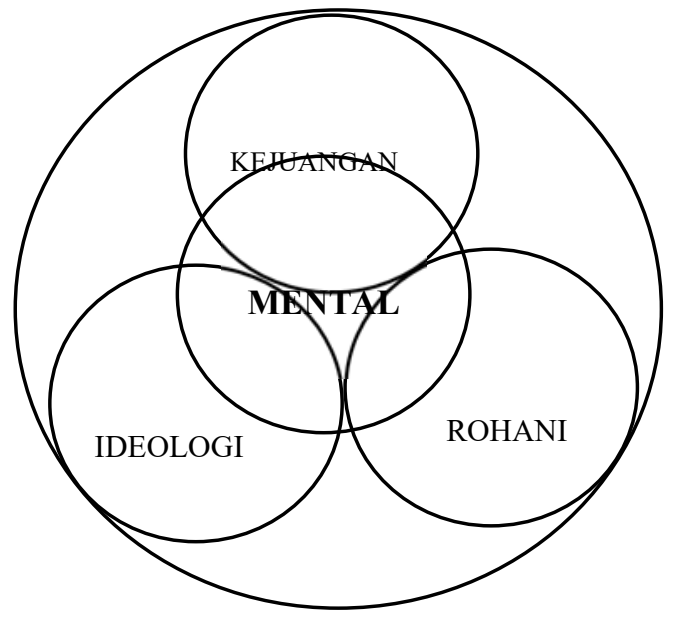

Gambar 2 . Sinergisme komponen bintal

Sumber :Dinas Pembinaan Mental Angkatan Darat

Hasil dari perpaduan (sinergisme) nilai-nilai Bintal akan memberikan suatu kualitas yang lebih tinggi dibandingkan sebelum terjadinya sinergisme, sebagai berikut:Pertama,Pembinaan Rohani yang bersumber dari ajaran agama dan diwarnai serta difasilitasi nilai-nilai ideologi dan kejuaangan akan melahirkan kualitas nilai antara lain:satu, Keimanan akan lebih subur, semakin kuat dan mantap serta tidak menjadi fanatisme sempit. Dua, Ibadah (pengabdian/ persembahyangan/kebaktian) akan lebih teratur, bersemangat dan bermakna luas (spiritual dan sosial).Tiga, Akhlak/moral akan lebih terpacu, luhur, teguh pada komitmen dan bermakna luas.Kedua, Pembinaan mental ideologi yang didasari oleh nilai-nilai rohani dan bersumber dari falsafah Pancasila serta diwarnai nilai kejuangan akan melahirkan kualitas nilai antara lain:satu, Kecintaan dan kesetiaan terhadap NKRI akan semakin meningkat, semakin tulus dan sejati.Dua,Kedisiplinan pribadi maupun sosialnya akan lebih hidup, sadar dan semakin berkembang.Tiga, Soliditas (kebersamaan dan kesatuan) akan lebih tulus, kokoh dan mantap. Ketiga,Pembinaan kejuangan yang didasari dan dijiwai oleh nilai-nilai rohani dan idiologi Pancasila serta bersumber dari sikap, perilaku pejuang yang bernilai positif dan konstruktif akan melahirkan kualitas nilai antara lain:satu,Semangat juang dan etos kerja akan lebih meningkat (bernilai ibadah).Dua, Keperwiraan (kepedulian keteladanan, keadilan, kejujuran dan rasa tanggung jawab) akan lebih murni, sejati dan sungguh-sungguh.Tiga, Jiwa pantang menyerah dan rela berkorban tanpa pamrih (disadari sebagai amanah Tuhan) sehingga pengabdiannya bersifat total dan handal.Nilai-nilai universal dari tiap komponen Bintal tersebut di atas yang telah dipadukan akan menjadi nilai-nilai Bintal yang utuh, bulat dan terpadu sehingga akan dapat membentuk sikap mental prajurit Sapta Marga yang tangguh, yang berciri takwa, nasionalis dan militan(Buku Petunjuk Pelaksanaan Penyelenggaraan Bintal.2014: 55) 
Keempat, Parameter Ketahanan Mental, Ketahanan mental dapat dilihat / diamati dari beberapa aspek yang merupakan parameter adanya ketahanan mental pada diri prajurit dan keluarganya, antara lain:pertama,Ditinjau dari aspek iman dan takwa satu,Memegang teguh norma-norma agama yang diyakininya, dua,Bergairah dalam kehidupan beragama, tiga,Taat dan tekun beribadah, empat,Memiliki akhlak terpuji (selalu bersyukur dan tahan uji), Kedua Ditinjau dari aspek nasionalisme, satuLoyal terhadap negara, satuan dan atasan, dua,Disiplin dan taat asas (berpegang teguh kepada prinsip / kebenaran), tiga,Pelanggaran rendah (bila terjadi bukan karena disengaja). Ketiga. Ditinjau dari aspek militansi, satu, Semangat / Moticasi tinggi dalam bertugas.Dua, Ulet bekerja / bertugas, pantang menyerah.Tiga, Malu jika gagal dalam melaksanakan tugas.

Kelima, Langkah-Langkah membangun pembinaan mental.Mewujudkan Pembinaan mental prajurit di satuan merupakan upaya dalam meningkatkan kualitas sumber daya manusia. Langkah-langkah untuk mewujudkan ketahanan mental tersebut meliputi pemberdayaan lembaga Bintalsat dan optimalisasi Bintal Fungsi Komando bisa di Satuan, kegiatan Bintal intensifkan dan pengamalan beragama semakin digairahkan dalam kehidupan para prajurit.Pertama,Pemberdayaan Lembaga Bintaldi KesatuanKita seringkali kurang memahami arti pentingnya lembaga Bintal di Satuan, karena pemahaman terhadap konsepsi Bintal belum komperhensifintegral. Disamping itu kemampuan para Pabintalsat juga belum sesuai harapan. Namun demikian kewajiban para Dansat adalah memberdayakan lembaga Bintal yang ada di Satuan dengan cara: Pertama,PersonelBagi satuan yang ada Pabintalnya agar diberdayakan secara optimal, sedangkan bagi satuan yang belum ada Pabintalnya supaya bersandar kepada Komando Atas atau satuan samping/tetangga. Dalam hal kerjasama pemanfaatan penceramah atau guru agama dari luar TNI, untuk mengeliminir keterpengaruhan prajurit dan keluarganya dari aliran-aliran sempalan maupun paham yang menyimpang, yang dimungkinkan masuk dan mempengaruhi prajurit beserta keluarganya. Oleh karena itu dalam hal kerjasama tersebut pemanfaatan penceramah atau guru agama dari luar TNI hendaknya, dilakukan secara selektif agar tidak terjadi kesalahan. Kedua,Peranti Lunak, Kebutuhan Penak dalam kegiatan Bintal menjadi demikian urgent, namun kebutuhan tersebut hingga saat ini belum mampu terdukung sepenuhya, sehingga tiap satuan diharapkan memenuhi kebutuhan Penak sesuai kemampuan satuan, dengan mengoptimalkan pemanfaatan Penak yang telah diterima dari Komando Atas dan mengajukan permintaan bantuan ke Depag setempat.

Ketiga,Metoda dan TeknikDalam kegiatan Bintal sering kali monoton dan kurang aplikatif, misalnya hanya ceramah dan pengajian. Padahal sesungguhnya masih banyak metoda dan teknik lain yang dapat dipilih dan diterapkan dalam kegiatan Bintal, misalnya metode dan teknik yang bersifat dialogis dan aplikatif antara lain: Satu, Dialog Prajurit, dialog keluarga prajurit dan sebagainya yang dilaksanakan dalam waktu tertentu dan pesertanya sesuai materi yang akan didialogkan / didiskusikan. Atau sebaliknya, peserta lebih dahulu ditentukan baru 
kemudian memilih materi yang sesuai dengan peserta dialog. Dua,Sosiodrama yaitu memperagakan penguasaan keterampilan di bidang Bintal seperti belajar ibadah dan sebagainya.Tiga, Pentas seni budaya dengan muatan materi Bintal seperti sandiwara, drama dan pentas musik bernuansa Bintal.Empat, Ibadah bersama sesuai agama masing-masing yang diselenggarakan oleh Satuan atau kompleks / perumahan secara terprogram untuk membiasakan diri prajurit beserta keluarganya sehingga dapat membudaya dalam beribadah..KeempatFasilitasPeran Dansat sangat menentukan dalam pemenuhan dukungan fasilitas penyelenggaraan kegiatan Bintal di Satuan. Dalam TA. 2017 ini Kasad telah menunjukkan komitmennya untuk memperbaiki mental prajurit dengan menaikkan anggaran kegiatan Bintal di tingkat Kotama dan Satuan setingkat Korem sebesar \pm 24,5 \%. Dana tersebut hendaknya dimanfaatkan seefisien mungkin untuk mendukung kegiatan Bintal di Satuan.

Keenam Optimalisasi Bintal Fungsi Komando (BFK) di SatuanHakikat BFK adalah peran serta seluruh unsur pimpinan, baik sebagai Dan / Ka maupun Pa Staf terhadap pembinaan mental dan anggotanya karena baik atau buruknya mentalitas anggota satuan adalah menjadi tanggungjawab sepenuhnya dari pimpinannya. Wujud tanggungjawab Dansat dan unsur pimpinan terhadap kondisi mental anggota di satuannya tersebut berupa: PertamaKepedulian.Satu, Mengamati kondisi mental prajurit dan keluarganya secara terus-menerus oleh Dansat dibantu Pa Staf dan Dansatwahnya.Dua, Mengevaluasi pelaksanaan kegiatan Bintal di satuan secara periodik maupun insidentil. Tiga, Mengarahkan staf yang terkait dengan penyelenggaraan kegiatan pembinaan mental di satuan (koordinator harian pejabat pers). Empat, Menyiapkan kader Bintal di satuan dengan merekrut anggota $\mathrm{Pa} / \mathrm{Ba} / \mathrm{TA} / \mathrm{PNS}$ ) yang mempunyai potensi menonjol di bidang Bintal, karena tidak semua satuan terpenuhi Pabintalnya. Kedua, KeteladananSetiap Dansat harus mampu menjadi panutan dalam sikap, tutur kata dan perbuatan yang terpuji. Karena itu untuk mewujudkan ketahanan mental anggota dan keluarga di satuannya setiap pimpinan hendaknya:satu,Menggiatkan pelaksanaan Bintal di satuan dengan sungguh-sungguh.

Dua, Selalu berupaya menjadi contoh / teladan bagi anak buah, tidak sekedar memberi contoh dengan kata-kata. Tiga, Selalu mengedepankan kejujuran (satu kata dengan perbuatan).Ketiga, KeadilanDalam mendukung kegiatan Bintal di Satuan perlu diperhatikan: satu, Menggiatkan Bintal di Satuan secara proporsional sesuai kebutuhan satuan dan tidak terjadi diskriminasi (SARA). Dua, Menegakkan reward and punishment secara adil dan mengutamakan pencegahan dari pada penindakan.Perlu disadari bahwa kegiatan Bintal di satuan pada dasarnya adalah tanggung jawab dari Dansat, sedangkan Pabintal hanyalah sebagai pelaksanan teknis dalam membantu Komandan Satuan. Disinilah sering terjadi kekeliruan atau salah paham dari sementara Dansat seolah-olah pembinaan Mental menjadi tanggung jawab dari Pabintal, sehingga Pabintal satuan bekerja sendiri tanpa dukungan yang memadai dari Komandan Satuan.

Ketujuh, Intensifikasi kegiatan Pembinaan MentalIntensifikasi kegiatan Bintal merupakan langkah yang perlu segeradigiatkan untuk terwujudnya ketahanan 
D. Rachyudi, Z. Abidin, Y. Z. Abidin

mental prajurit beserta keluarnganya. Hak ini dapat dilaksanakan melalui kegiatankegiatan sebagai berikut: kesatuDalam Proses seleksi mentalMateri seleksi mental bagi calon prajurit hendaknya secara utuh yang meliputi bidang mental rohani, mental ideologi dan mental kejuangan. Hasilnya diharapkan mampu mendapatkan calon prajurit yang mempunyai latar belakang atau dasar mental yang baik karena faktor dasar lebih dominan dari faktor dasar. (Farid Ma'ruf Noor 1981:37) Disamping itu pada saat calon prajurit masih dikarantina perlu mendapatkan siraman rohani agar mereka percaya diri seraya lebih mendekatkan diri kepada Tuhan Yang Maha Esa, sehingga bila mereka gagal tidak terlalu kecewa, dan apabila mereka berhasil lulus tidak lupa diri karena gembira yang berlebihan. Kedua, Dalam PendidikanKetika calon prajurit lulus seleksi dan telah memasuki masa pendidikan perlu mendapatkan pembinaan mental secara intensif melalui program pengajaran dan Bimsuh yang bersifat ekstra kurikuler. Dalam program bimbingan dan pengasuhan dititik beratkan pada bidang agama. Di lembaga pendidikan Pembinaan Mental tidak cukup hanya diberikan dalam bentuk mata pelajaran, karena jumlah jam pelajaran Bintal sangat terbatas (sedikit), sehingga akan lebih efektif dan bermanfaat apabila diberikan melalui pengasuhan oleh infrastruktur atau pembina.

Ketiga, Dalam KesatuanUntuk mengintensifkan kegiatan Pembinaan Mental dalam kehidupan prajurit di satuan atau tempat penugasan, dapat dilaksanakan melalui perencanaan yang matang dengan langkah-langkah sebagai berikut: satu, Kegiatan Bintal seharusny a terjadual secara mingguan dan dievaluasi perkembangannya. Dua, Dalam latihan dan kegiatan satuan, hendaknya waktu ibadah harus mendapatkan perhatian khusus sehingga setiap prajurit terbiasa melaksanakan ibadah tepat waktu.

Tiga, Mengaktifkan kegiatan Bintal untuk Persit KCK dan keluarga. Jangan sampai kegiatan istri dan keluarga prajurit lebih banyak didominasi untuk menonton infotainment tentang gossip show dan sinetron yang kurang mendidik moralitas, sehingga dampaknya mengganggu dan bahkan mengancam kerukunan dan kebahagiaan rumah tangga. Empat,Memberikan pembekalan pranikah dan bimbingan rumah tangga bahagia bagi prajurit dan keluarganya, agar tiap prajurit dapat memilih dengan tepat calon pasangannya. Bagi prajurit yang sudah berkeluarga agar memiliki ketahanan rumah tangga yang baik, selanjutnya pedomani buku petunjuk NTCR yang baru, agar pelayanan dapat diberikan secara cepat dan tepat. Lima,Melaksanakan Pekan Bintal Terpadu (PBT), Pekan Disiplin dsb. Dalam penyelenggaraanmya di satuan bersifat terpadu baik materi maupun institusi, dimana pejabat pers satuan sebagai koordinator dibantu Pabintal sebagai pelaksana harian yang didukung unsur POM / Provost, Hukum dan Kesehatan satuan atau Satuan atas. Selama sepekan ciptakan suasana ketaatan terhadap norma agama dan peraturan yang berlaku dengan mengemas jadual mingguan dalam pelaksanaan kegiatan PBT tsb tiap harinya terdapatkegiatan yang sarat dengan nilai-nilai mental, Kegiatan PBT sangat penting diselenggarakan secara serentak oleh tiap satuan dalam rangka perang terhadap pelanggaran, baik dilaksanakan 
secara stimulan maupun bertahap atau berturut-turut, yang terpenting sasaran bisa tercapai. Keempat, Dalam Lingkungan Keluarga dan MasyarakatKetika prajurit telah berkeluarga dan hidup di tengah masyarakat, maka upaya pembinaan mental secara utuh juga harus terus dilakukan secara intensif. Pembinaan mental dalam keluarga serta pembinaan dalam kehidupan bermasyarakat juga perlu diintensifkan, agar prajurit beserta keluarganya memiliki ketahanan mental yang baik. Karena prajurit beserta keluarganya selalu hidup bermasyarakat, sesuai dengan hakikat jati diri prajurit TNI yang selalu maunggal dengan rakyat. Oleh karena itu setiap perwira/Bintara/Tamtama dan keluarga hendaknya bisa menjadi panutan dalam sikap dan prilakunya ditengah tengah masyarakat.( Rifa'i, 2007: 34)

Kedelapan, Penggairahan Beragama dalam Kehidupan Prajurit.Dalam upaya mewujudkan keimanan dan ketaqwaan tidak terlepas dari penggairahan kehidupan beragama dengan intensifikasi kegiatan Bintal yang difasilitasi oleh Komandan satuan, dari hulu sampai hilir, yaitu mulai dari kehidupan pribadi, keluarga dan satuan. Upaya penggairahan kehidupan beragama juga harus melekat dalam semua aspek kehidupan prajurit yaitu dengan kegiatan sebagai berikut (Hasil Litbang Disbintalad 2009): pertama, Tiap prajurit dan keluarganya didorong mandiri dalam meningkatkan kualitas kehidupan beragama. Setiap pribadi prajurit dan keluarganya mempunyai tanggung jawab dalam menjalankan kewajiban agamanya atau beribadah sesuai dengan agamanya. Beribadah dalam agama merupakan kewajiban individu, disamping mempunyai manfaat yang cukup banyak, baik manfaat untuk kehidupan dunia maupun untuk kehidupan akhirat. Dalam kehidupan dunia ibadah tidak terlepas dari mu'amalah. Tujuannya agar ibadah bermanfaat dalam mencegah manusia dari perbuatan keji dan munkar (pelanggaran). Contohnya dalam agama Islam ada firman Tuhan yang artinya: “ Dirikanlah shalat sesunggubnya shalat itu mencegah diri dari perbuatan keji dan munkar" (Q.S., Al Ankabut: 45). (Al-Qur'an dan Terjemahannya)Melaksanakan Tri Sadhya (tiga waktu sembahyang pagi, siang dan sore hari).

Pemahamannya, bahwa shalat atau ibadah itu akan mendekatkan diri kepada Tuhan. Bila dekat dengan Tuhan hati akan semakin suci sehingga terhindar dari pengaruh syetan, untuk tidak melakukan pelanggaran.Begitu juga dengan pembinaan keluarga, yang merupakan organisasi terkecil dalam kehidupan bermasyarakat, berbangsa dan bernegara. Baik dan buruknya kehidupan suatu masyarakat atau suatu bangsa sangat ditentukan oleh kehidupan berkeluarga. Untuk mewujudkan kehidupan masyarakat dan bangsa yang baik, perlu ditingkatkan pembinaan kehidupan beragama dalam keluarga. Manfaat yang diperoleh dari pembinaan kehidupan beragama dalam keluarga, yaitu:kesatu, Mental anggota keluarga mempunyai dasar agama yang kuat yaitu iman dan takwa.Kedua, Hubungan keluarga akan harmonis, terhindar dari rasa ketidak puasan, perselisihan dan perselingkuhan. Ketiga, Sebagai dasar utama untuk terwujudnya keluarga yang sejahtera dan bahagia.Kedua,Komandan satuan mengarahkan dan memfasilitasi setiap kegiatan keagamaan di satuan. Melaksanakan ibadah kepada Tuhan TME merupakan tanggung jawab masing- 
D. Rachyudi, Z. Abidin, Y. Z. Abidin

masing pribadi prajurit, namun Komandan Satuan juga mempunyai kewajiban dalam memfasilitasi serta mendorong semua anggotanya agar mempunyai kesadaran dalam menjalankan kewajiban sesuai dengan keyakinan agamanya. Apabila dalam satu kesatuan komandan punya komintmen dalam menjalankan agama, maka kehidupan beragama di satuan tersebut akan bergairah. Semua anggota dan staf akan mengikuti semua kegiatan keagamaan lantaran komandan aktif dalam kegiatan agama. Akan tetapi bila dalam satu kesatuan, komandan tidak punya komitmen dalam menjalankan kegiatan agama, maka anggota dan staf juga tidak akan bergairah dalam mengikuti serta menjalankan setiap kegiatan keagamaan. Oleh karena itu untuk menggairahkan kehidupan beragama dalam satu kesatuan sangat dituntut peran aktif dari Dansat.

Ketiga,Menyelenggarakan lomba keagamaan seperti; MTQ, Pesparawi, Utsawa Dharma Ghita, cerdas cermat tentang pengetahuan agama. Keempat,Menyelenggarakan peringatan hari-hari besar agama tidak sekedar seremonial, akan tetapi diharapkan bermakna bagi upaya penggairahan agama di satuan.Kelima, Membentuk kelompok belajar agama sesuai dengan segmentasi, dan tingkat kemampuan anggota di Satuan. Contoh: Pada bulan Ramadhan tahun 2017 Madivif 1 / Kostrad telah mempelopori penerapan kegiatan ini.

\section{PENUTUP}

Berdasarkan hasil kajian secara teoritis maupun empiris serta berdasarkan analisis temuan di lapangan, data yang dikemukakan pada bab-bab terdahulu maka, dapat ditarik kesimpulan bahwa;

Pertama. Akibat pengaruh lingkungan yang tidak kondusif baik yang bersifat internal maupun eksternal sebagian dari prajurit belum memiliki aspek kondisi mental yang baik akibatnya mudah terpengaruh oleh karena itu perlunya pejabat rohis bintal memberikan perhatian dan arahan melalui kegiatan bintalrohis dengan kajian ayat-ayat al-quran dan hadis yang menjelaskan tentang pelanggaranpelanggaran beserta konsekwensinya.

Kedua, Prajurit yang berprestasi dalam menghentikan dan meniadakan pelanggaran akan dapat dilihat dari semangat jiwa korsa, rajin, ulet dan kondusifnya suasana di lingkungan satuan konsekwensi ini menunjukan bahwa konteks memahami dengan benar para prajurit adalah suatu prestasi terbaik setelah menyimak indikator-indikator pemahaman dakwah di kalangan prajurit yang disampaikan komando, dapat di pahami dan diaktualisasikan secara nyata di lapangan.

Ketiga, Dakwah yang disampaikan kepada para prajurit yang meliputi seluruh pola kegiatan pembinaan mental adalah merupakan segala bentuk usaha, tindakan dan upaya untuk membentuk, memelihara, meningkatkan dan memantapkan kondisi jiwa dari para prajurit baik dari unsur jasmani, akal dan rohani serta unsurunsur lainnya yang berkaitan erat dengan manusia seutuhnya, agar penyelenggaraan kegiatan dakwah melalui pembinaan mental di kalangan prajurit 
lebih efektif dan lebih efisien dalam pelaksanaannya tidak hanya dilakukan oleh institusi/pejabat bintaldam III/Slw saja akan tetapi dengan melibatkan juga institusi/pejabat korps polisi militer, korps kesehatan medis, korps hukum, dinas jasmani dan instansi kementrian agama secara serentak/ bersama-sama.

\section{DAFTAR PUSTAKA}

A.Mangunhardja, Pembinaan Arti dan Metodenya, (Yogyakarta: Kanisius, 1986)

Abdul Kadir Munsyi, Metode Diskusi dalam Da'wah, (Surabaya: Al Ikhlas, 1981)

Al-Qur'an dan Terjemahannya, PT Syamil Cipta Media Bandung Departemen Agama RI

Buku Petunjuk Pelaksanaan Penyelenggaraan Bintal jajaran wilayah Kodam III/Slw (Bintaldam III/Slw, Bandung 2014)

Buku, Pembekalan materi Bintal Angkatan Darat, (Disbintalad Jakarta 2007)

Dinas pembinaan Mental Angkatan Darat :Materi pembinaan mental terpadu, CV. Ami Global Media 2007

Dokumen arsip pembinaan mental Kodam III'Slw. Kantor Bintaldam III/Slw Jl. Lembong Bandung tanggal 18 Desember 2017

Dokumen Balak Bintaldam III/Slw, Bandung 2016

Drs. H. Moch. Rifa'I :Percikan Iman, (Cv. Citra Harta Prima Jakarta 2007)

Farid Ma'ruf Noor, Dinamika dan Akhlak Dakwah, (Surabaya: PT. Bina Ilmu, 1981)

Hasil Litbang Bintalad terhadap keteladanan unsur pimpinan satuan tingkat Batalyon pada 2016

Hasil operasi Yustisi 2017 Pomdam III/Slw terjadi kenaikan pelanggaran prajurit.

Mabes ABRI, Himpunan Istilah Pembinaan Mental ABRI, Jakarta: Pusat Pembinaan Mental ABRI, 1990)

Anas, Ahmad, \& Hendri Hermawan Adinugraha. "Dakwah Nabi Muhammad terhadap Masyarakat Madinah Perspektif Komunikasi Antarbudaya." Ilmu Dakwah: Academic Journal for Homiletic Studies [Online], 11.1 (2017): 5372. Web. 1 Jul. 2018

Bahrudin, Bahrudin. "Prinsip-prinsip Komunikasi dalam Al-Qur'an." Ilmu Dakwah: Academic Journal for Homiletic Studies [Online], 5.15 (2010): 827-848. Web. 1 Jul. 2018

Mirza, Iskandar. Simbologi Al-Qur'an: Sebuah Kontribusi untuk Pemetaan Karakter Manusia sebagai Objek Dakwah. Ilmu Dakwah: Academic Journal for Homiletic Studies, 4.11 (2008): 177-192. Web. 1 Jul. 2018

Muhyiddin, Asep. "Dakwah Lingkungan Perspektif Al-Qur'an." Ilmu Dakwah: Academic Journal for Homiletic Studies [Online], 5.15 (2010): 809-826. Web. 1 Jul. 2018

Muhyiddin, Asep. "Tema Sentral Dakwah Qur'ani." Ilmu Dakwah: Academic Journal for Homiletic Studies [Online], 1.1 (2002): 149-206. Web. 1 Jul. 2018 
D. Rachyudi, Z. Abidin, Y. Z. Abidin

Nawawi, Nawawi. "Dakwah Keluarga: Internalisasi Nilai-nilai Budi Pekerti dalam Keluarga Jawa." Ilmu Dakwah: Academic Journal for Homiletic Studies [Online], 6.2 (2012): 285-311. Web. 1 Jul. 2018

Rasyid, Abdul. "Freedom of Speech: Dimensi Kebebasan dalam Paradigma Komunikasi Dakwah." Ilmu Dakwah: Academic Journal for Homiletic Studies [Online], 4.11 (2008): 67-88. Web. 1 Jul. 2018

Saefullah, Ujang. "Dinamika Komunikasi dalam Mewujudkan Kerukunan Hidup antarumat Beragama." Ilmu Dakwah: Academic Journal for Homiletic Studies [Online], 5.17 (2011): 411 - 444. Web. 1 Jul. 2018

Tajiri, Hajir. "Pendekatan Dakwah Etis terhadap Kondisi Masyarakat Muslim Heterogen. Ilmu Dakwah: Academic Journal for Homiletic Studies [Online], 4.11 (2008): 89-110. Web. 1 Jul. 2018

Triyana (2014). Pembinaan Mental Prajurit di Wilayah Korem 171 Praja Vira Tama Sorong Papua Barat, Tesis Universitas Islam Negeri Alauddin Makassar.

Wardoyo, Ali (2015). Pola-pola Komunikasi Dakwah Perwira Rohani Islam di Markas Komando Armada RI Kawasan Timur, Tesis Universitas Islam Negeri Sunan Ampel Surabaya.

Sapari (2016). Pembinaan Mental Prajurit TNI Angkatan Udara Makoopsau II Ditinjau dari Segi Pendidikan Islam, Tesis Universitas Islam Negeri Alauddin Makassar 2016 